http://jmscr.igmpublication.org/home/

ISSN (e)-2347-176x ISSN (p) 2455-0450

crossref DOI: https://dx.doi.org/10.18535/jmscr/v8i7.100

Journal Of Medical Science And Clinical Research

\title{
Study of Stridor in Adults
}

\author{
Authors \\ Dr Deepak Parmar ${ }^{1}$, Dr Vinay Gangwani ${ }^{2 *}$, Dr Jyoti Sharma ${ }^{3}$ \\ ${ }^{1}$ RSO Dept of ENT Gajra Raja Medical College Gwalior \\ ${ }^{2}$ Consultant ENT at Sachkhand Hospital Neemrana, Alwar Rajasthan \\ ${ }^{3}$ RSO Dept of ENT Gajra Raja Medical College Gwalior \\ *Corresponding Author \\ Dr Vinay Gangwani
}

\section{Introduction}

Stridor is an abnormal, harsh, high pitched, turbulent musical breathing sound caused by partial obstruction in the larynx/tracheobronchial tree and is usually associated with dyspnea. stridor indicates an emergency and should always evaluate immediately. ${ }^{1}$

Stridor is an Emergency Condition. Its indicates an obstruction of the airway. Stridor in adult a manifestation of airway obstruction, due to growth larynx, larynx edema etc.

It is more common in males than females. Growth larynx was once one of the most common causes of airway obstruction.

Early detection of stridor is very important to avoid the complications. Some symptoms such as Dyspnea, excessive use of respiratory muscles and intercostal recession are important warning signs that the airway obstruction is severe enough to compromise the airway ventilation.

There are several important signs and symptoms which a physician should look out for increasing severity of the airway obstruction. The warning signs of stridor are presence of drooling, tripod position, cyanosis, decreased conscious level, respiratory distress, silent chest, and episodes of apnoea. $^{2}$

It is important that a proper history taking and physical examination are the important key in assisting the physician in the diagnosing and management of stridor in the emergency department. Delay or misdiagnose the cause of the stridor may lead to mismanagement of the patient and causing very serious morbidity. ${ }^{3}$

Signs and symptoms associated with stridor in adults:

Symptoms: Dyspnea, Dysphagia, change in voice, neck swelling, hoarseness, cough, pain in throat.

Signs: use of accessory muscles during respiration, swelling of lips and tongue in anaphylaxis reaction /acid dye ingestion/thermal burn, floor of mouth raised, tripod position etc.

Stridor may be heard during inspiration, expiration or both.

Inspiratory stridor is often produced in the obstructive lesions of supraglottis or pharynx e.g. retropharyngeal abscess. 
Expiratory stridor is produced in the disease involving thoracic trachea, Bronchus e.g. growth tracea, tracheal stenosis

Biphasic stridor is seen in disease involving of glottis, subglottis and cervical trachea e.g. laryngeal papilloma, vocal cord paralysis and subglottic stenosis. ${ }^{4}$

\section{Common causes of stridor in adults}

Trauma to neck- Road Traffic Accident (RTA), strangulation, ludwigs angina, parapharyngeal abscess, Tumours of larynx, vocal cord paralysis, thyroid malignancy, thermal burns, acid dye ingestion, tetanus.

India is another developing country that prevailing lower SES, smoking and drinking habits, poor general health of population, environmental factors that increase the incidence of stridor.

Stridor is different from stertor which is a low pitched snoring type sound. It is generated at the level of nasopharynx and oropharynx.

\section{Materials \& Methods}

The study entitled to "Study of Stridor in Adults" conducted in the department of ENT in government Medical College for a period of 1 year from January 2018 to December 2018. A total of 50 cases presenting with STRIDOR in the ENT emergency were taken for study.

\section{Inclusion Criteria}

- All patients presenting with stridor at ENT emergency, medicine and surgery ICU.

\section{Exclusion Criteria}

- Patients with snoring, nasal obstructive diseases.

\section{Results}

Table No. 1: Incidence of stridor in Different Age Groups

\begin{tabular}{|l|c|c|}
\hline Age group (years) & No. of cases & Percentage \\
\hline 16-20 year & 04 & $08 \%$ \\
\hline 21-25 year & 04 & $08 \%$ \\
\hline 26-30 year & 04 & $08 \%$ \\
\hline 31-35 year & 02 & $04 \%$ \\
\hline 36-40 year & 07 & $14 \%$ \\
\hline 41-45 year & 04 & $08 \%$ \\
\hline 46-50 year & 04 & $08 \%$ \\
\hline 51-55 year & 05 & $10 \%$ \\
\hline 56-60 year & 04 & $08 \%$ \\
\hline 61-65 year & 03 & $06 \%$ \\
\hline $66-70$ year & 04 & $08 \%$ \\
\hline $71-75$ year & 01 & $02 \%$ \\
\hline $76-80$ year & 01 & $02 \%$ \\
\hline $81-85$ year & 02 & $04 \%$ \\
\hline $86-90$ year & 01 & $02 \%$ \\
\hline$>90$ year & - & - \\
\hline TOTAL & 50 & $100 \%$ \\
\hline
\end{tabular}

In the present table, the peak incidence of stridor was found in the age group between 36-40 years (14\%) followed by $51-55$ year $(10 \%)$

Table No. 2: Sex wise distribution of patients

\begin{tabular}{|l|c|c|}
\hline Sex & No. of cases & Percentage \\
\hline Male & 35 & $70 \%$ \\
\hline Female & 15 & $30 \%$ \\
\hline Total & 50 & $100 \%$ \\
\hline
\end{tabular}

The incidence of stridor was observed to be more in males $(70 \%)$ than females $(30 \%)$.

Table No. 3: Types of stridor

\begin{tabular}{|l|c|c|}
\hline Type of stridor & No. of Cases & Percentage \\
\hline Inspiratory & 33 & $66 \%$ \\
\hline Expiratory & 11 & $22 \%$ \\
\hline Biphasic & 06 & $12 \%$ \\
\hline Total & 50 & $100 \%$ \\
\hline
\end{tabular}

Most common type of stridor is inspiratory $66 \%$ followed by expiratory $22 \%$ least common is biphasic $12 \%$.

Table No. 4: Duration of stridor

\begin{tabular}{|l|c|c|}
\hline Time Period & No. of Cases & Percentage \\
\hline$<1 \mathrm{Wk}$ & 35 & $70 \%$ \\
\hline $1-12 \mathrm{Wks}$ & 08 & $16 \%$ \\
\hline 3 Months -6 Months & 06 & $12 \%$ \\
\hline$>6$ Months & 01 & $02 \%$ \\
\hline Total & 50 & $100 \%$ \\
\hline
\end{tabular}


In our study $70 \%$ patients were having stridor for duration<1 week, $16 \%$ patients were having stridor for duration 1-12 weeks, $12 \%$ patients were having stridor for duration 3 months to 6 months, only $2 \%$ patients were having stridor for duration $>6$ months.

Table No. 5: Clinical presentation of patients with stridor

\begin{tabular}{|l|c|c|}
\hline Clinical presentation & No. of cases & Percentage \\
\hline Noisy breathing & 50 & $100 \%$ \\
\hline Difficulty in breathing & 45 & $90 \%$ \\
\hline Difficulty in swallowing & 23 & $46 \%$ \\
\hline Change in voice & 20 & $40 \%$ \\
\hline Swelling in neck & 15 & $30 \%$ \\
\hline Pain in throat & 10 & $20 \%$ \\
\hline Cough & 35 & $70 \%$ \\
\hline Fever & 20 & $40 \%$ \\
\hline Hoarseness of voice & 15 & $30 \%$ \\
\hline
\end{tabular}

In our study noisy breathing $100 \%$ was the most common associated complain followed by $90 \%$ difficulty in breathing and least common associated complaint was hoarseness of voice $(15 \%)$.

Table No. 6: Causes of stridor

\begin{tabular}{|l|c|c|}
\hline Causes of stridor & No. of cases & Percentage \\
\hline Growth larynx & 20 & 40 \\
\hline Ludwigs angina & 10 & 20 \\
\hline $\begin{array}{l}\text { Larynx edema } \\
\text { (burn \& acid ingestion) }\end{array}$ & 08 & 16 \\
\hline Larynx trauma & 06 & 12 \\
\hline Ca thyroid & 02 & 04 \\
\hline Tetanus & 01 & 02 \\
\hline Vocal cord palsy & 01 & 02 \\
\hline Retropharyngeal abscess & 01 & 02 \\
\hline Parapharyngeal abscess & 01 & 02 \\
\hline TOTAL & 50 & 100 \\
\hline
\end{tabular}

Among various causes of stridor growth larynx was the most common cause of stridor $40 \%$, followed by ludwigs angina $20 \%$, and least common causes were vocal cord palsy $1 \%$, Retropharyngeal abscess $1 \%$, parapharyngeal abscess $1 \%$, tetanus $1 \%$.
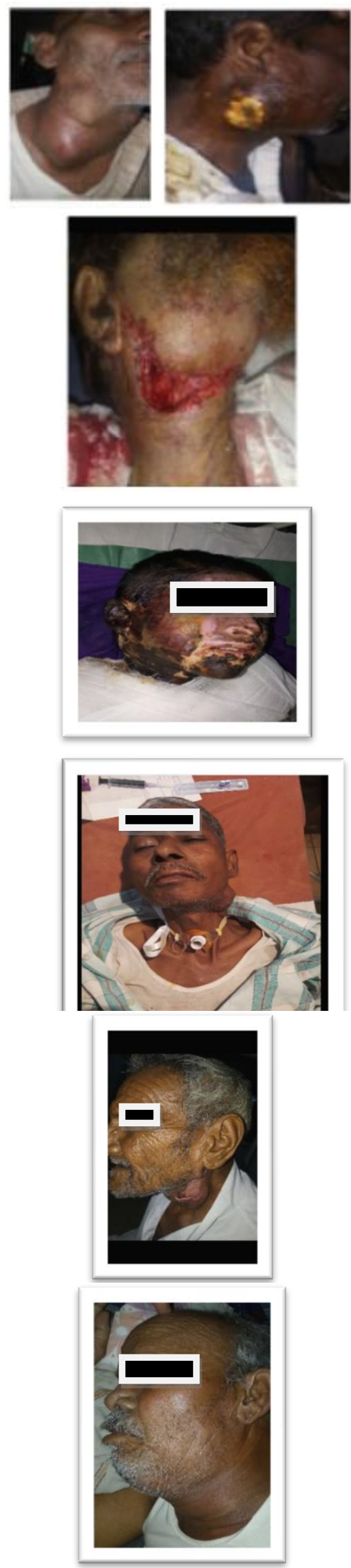
Table No. 7: Treatment of stridor

\begin{tabular}{|l|l|}
\hline Causes of stridor & Management \\
\hline Growth larynx & $\begin{array}{l}\text { Emergency Tracheostomy and direct } \\
\text { laryngoscopy and biopsy }\end{array}$ \\
\hline $\begin{array}{l}\text { Retropharyngeal } \\
\text { abscess }\end{array}$ & Incision and drainage \\
\hline Larynx edema & Tracheostomy \\
\hline Larynx trauma & Tracheostomy \\
\hline Ludwigs angina & Incision and drainage, tracheostomy \\
\hline
\end{tabular}

In our study Tracheostomy done in 50\%, Direct laryngoscopy and biopsy taken in $20 \%$,incision and drainage $12 \%$, conservative management $10 \%$, medical management $9 \%$

\section{Discussion}

The present study entitled "Study of Stridor in Adults" at Government medical college. Study period from January 2018 to December 2018 on 50 patients with stridor.

\section{Age Distribution}

In our study it was observed that most of the patient belong to age group 36-40 years (14\%) followed by 51-55year 10\%,41-50 years(10 years)Overall age distribution :-36-55 year age is $40 \%$.

\section{Sex Distribution}

Out of 50 patients $70 \%$ male and $30 \%$ female.

male : female ratio is $1.7: 1$ also found that stridor was more common in males. More common in Male because of different habits eg. smoking, chewing tobacco, alcohol intake which is not common in females in india.

\section{Duration of Stridor}

In our study $70 \%$ patients were having stridor for duration <1 week followed by $16 \%$ patients having stridor for duration 1-12 week, $12 \%$ patients having stridor for duration 3 months -6 months, only $2 \%$ having stridor for duration $>6$ months.

\section{Types of Stridor}

In our study most common type of stridor is inspiratory $66 \%$ followed by expiratory $22 \%$ and Biphasic $12 \%$.

\section{Causes of Stridor}

Adult patients 50 cases
Most common is growth larynx $40 \%$ followed by ludwigs angina $20 \%$, larynx edema $16 \%$, larynx trauma $12 \%$,vocal cord palsy $2 \%$, ca thyroid $4 \%$, tetanus $2 \%$, epiglottitis $2 \%$, parapharyngeal abscess $2 \%$.

\section{In comparison with the following studies:}

Vasileios zochios $(2015)^{5}$

In this study total cases are 249 with 99 publications.

In this study commonest systemic cause of stridor is neurological $26 \%$ followed by psychogenic stridor in $21.2 \%$,vocal cord disease $10.8 \%$, esophageal and autoimmune $7.2 \%$, primary airway lesion $6.8 \%$, thyroid and parathyroid disease 5\%, infectious, inflammatory and immunodeficiency $3.6 \%$, exercise in elite athletes $7.6 \%$, thoracic aortic aneurysm $1 \%$.

In our study most common cause of stridor in adult is growth larynx $40 \%$ followed by ludwigs angina $20 \%$, larynx edema $16 \%$.

- This study is done in developed country (U.K.) So patient presents early and undergo early diagnosis and treatment. Where as in our country the patients remain undiagnosed till they develop respiratory distress, change in voice and other symptoms.

- Growth larynx is most common in our study because carcinoma larynx is more common in our country as compare to other countries.

Carcinoma larynx is the ninth and seventh most common cause of cancer. In males in Asia and India respectively.

- India is another developing country prevailing lower SES, tobacco chewing, smoking and drinking habits, poor general health of population ,environmental and different social customs definitely increase the incidence of carcinoma larynx.

- A higher incidence of growth larynx in our study could be explained by the fact that our medical college and hospital is only government medical college and hospital for a large population, with well equipped operation theatre and well functioning 
pathological laboratory where histopathology is available which helps in making diagnosis of carcinoma larynx .There is also separate oncology department in our medical college so patients are referred from surrounding areas.

\section{Management of Stridor}

In our study Tracheostomy done in 50\% patients, Direct laryngoscopy and biopsy taken in $20 \%$,incision and drainage $12 \%$, conservative management $10 \%$, medical management $9 \%$.

\section{In accordance with the following studies:}

\section{Rupa v., Raman R.(1990) ${ }^{6}$}

Tracheostomy was done in $25 \%$ of patients.2. Waalkens HJ et al (1989) $)^{7}$ Intubation and tracheostomy performed in $33.3 \%$ patients.

\section{Conclusion}

The present study was undertaken to study of stridor in adults among the patients attending the E.N.T department in Government Medical college total of 50 patients were included in the study. stridor is a emergency condition and severe airway obstruction which needs emergency management. stridor for longer duration may be because of underlying malignancy so every patient with stridor should be investigated thoroughly and managed accordingly.

Direct laryngoscopy proved to be useful method in detecting various causes of stridor. Direct laryngoscopy and Biopsy should be taken from any growth or any suspicious area of lesion of larynx for the confirmation of diagnosis so that proper treatment can be given.

In our study most commonly affected age group with complains of stridor is 36-55 years (40\%)with majority of them were males. M.C. cause is growth larynx. Since our study is a Government Institution based study and patients in the institution are more from low socioeconomic strata, which are more prone to laryngeal infections and cancer larynx due to their poor nutrition, addiction habits and occupational exposure.
Benign lesion and malignancy larynx are more common in patients between 35-55 years of age group. Smoking is also a contributing factor causing persistent inflammation and irritation of the larynx.

Management of stridor is according to the cause of stridor.

Growth larynx-tracheostomy followed by direct laryngoscopy and biopsy taken from growth and send for Histopathological examination (HPE).

Tracheostomy done in larynx trauma, edema of larynx,vocal cord paralysis, tetanus, carcinoma thyroid patients.

Ludwigs angina-incision and drainage and tracheostomy if needed.

Retropharyngeal abscess-intraoral incision and drainage.

parapharyngeal abscess-external incision and drainage.

In our study Tracheostomy done in 50\% patients, Direct laryngoscopy and biopsy taken in $40 \%$ and sent for HPe, incision and drainage in $12 \%$, conservative management $10 \%$, medical management $9 \%$.

\section{References}

1. Textbook of Ear, Nose, Throat and Head and Neck Surgery, P. Hazarika, $3^{\text {rd }}$ edition, page 654.

2. Majumdar S, Bateman NJ, Bull PD. Pediatric stridor. Arch Dis Child Educ Prac Ed 2006;91:101-105.

3. Mohamad N, Sjam'un A, Ismail F, Solayar LD, Mohamed SA et al. Acute stridordiagnostic challenges in different age groups presented to the emergency department. Emergency Med Med 2012;2:125.

4. PL Dhingra, Shruti Dhingra. Disease of ear, nose and throat, 5th edition, Elsevier, Page 315.

5. Stridor in adult patients presenting from community: An Alarming clinical sign. Vasileios zochios, Aristotle D protopapas 
and Kamen valchanov. Journal intensive care soc.2015 aug;16(3):272-273.

6. Aetiological profile of paediatric laryngeal stridor in an indian hospital. VEDANTAM RUPA AND RAJAGOPALAN RAMAN. annuals of Tropical paediatrics (1991)11,137-141.

7. Stridor in children Waalkens $\mathrm{HJ}$,et al Wouters b, Zwaaans-Hesselink AG, Gerritsen J. Ned Tijdschr Geneeskd.1989 oct 7;133(40):1981-4. 